\title{
GLOBAL GOVERNANCE IN ALL ITS DISCRETE FORMS: THE GAME, FIFA, AND THE THIRD WORLD
}

\author{
Basil Ugochukwu*
}

This paper uses the governance praxis of the Federation of International Football ${ }^{1}$ Associations [FIFA] to illustrate the impact of several intensive, discrete, and rarelystudied global governance actors whose internal processes and procedures mirror the core concerns of Third World Approaches to International Law [TWAIL] scholars regarding the legitimation of a hegemonic category and the marginalization of Third World and subaltern interests. It is argued that FIFA has become an important international organization and global governance actor whose transnational rule-making characteristics should be studied in light of the incipient migration from "international law" to "global governance". 2

It will be shown that not only are FIFA's rules impinging on sovereign imagination but that the tendencies of inequality, unfairness and domination afflicting the practices of traditional or state-centric international organizations are as prevalent in the procedures of such less-studied global governance actors regardless that their rule-making activities exert significant impact on governments, especially those in Africa and other parts of the Third World. More significantly, the essay looks at possible domestic political and sociolegal implications of discrete globalization of the kind exemplified by FIFA on Africa and the Third World and how important it is to integrate this concern into TWAIL scholarship going forward.

Dans cet article, l'auteur cite les activités de gouvernance de la Fédération Internationale de Football Association [FIFA] pour illustrer l'impact de plusieurs acteurs de la gouvernance mondiale très actifs, discrets et faisant rarement l'objet

* Post-Doctoral Fellow (International Law), Centre for International Governance Innovation, Waterloo, Canada. I am grateful to the anonymous reviewers for their helpful feedback. My gratitude goes as well to Obiora Okafor, Peer Zumbansen, Tyler McCreary, Julia Dehm, Asad Kiyani, John Reynolds, Jerusa Ali, Amaya Alvez, Heidi Matthews, Sujith Xavier, Ximena Sierra-Carmago and Srinivas Burra for their kind comments/suggestions on initial drafts of this paper. Hold me responsible for all remaining errors.

1 Football, as a sport, is also known as "soccer" in North America. The two terms shall be used interchangeably in this paper and are taken to mean one and the same thing. The paper is not intended to discuss why it is referred to as "football" in Europe and other parts of the world, while referred to as "soccer" in North America, even if that discussion could provide some insights into governance, cultural and inclusivity questions that are raised. It should be enough to say that American exceptionalism is nothing new even in sports, and that "status rivalry", as some have argued, could be the reason for America's adoption of a less English name for the same sport. See for example Ivan Waddington \& Martin Roderick, "American Exceptionalism: Soccer and American Football" (1996) 16 Sports Historian 28 at 43; Andrei Markovits \& Steven Hellerman, Offside: Soccer \& American Exceptionalism (Princeton, NJ: Princeton University Press, 2001).

2 See Joel Ngugi, "Making New Wine for Old Wineskins: Can the Reform of International Law Emancipate the Third World in the Age of Globalization?” (2002) 8 U Cal Davis J Intl L \& Pol'y 73. 
d'études, dont les mécanismes et procédures internes rappellent les principales préoccupations des universitaires des Third World Approaches to International Law [TWAIL] en ce qui touche la légitimation d'une catégorie hégémonique et la marginalisation du tiers monde et des intérêts subalternes. L'auteur soutient que la FIFA est devenue une organisation internationale importante et un acteur de la gouvernance mondiale dont les caractéristiques en matière d'établissement de règles transnationales devraient être étudiées dans le cadre du passage du "droit international » à la "gouvernance mondiale " qui s'amorce.

L'auteur démontre non seulement que les règles de la FIFA ont un effet sur l'imagination souveraine, mais aussi que les tendances d'inégalité, d'iniquité et de domination affligeant les pratiques des organisations internationales traditionnelles ou statocentriques prévalent tout autant dans les procédures des acteurs de la gouvernance mondiale peu étudiés, malgré le fait que leurs activités d'établissement de règles ont des répercussions non négligeables sur les gouvernements, surtout ceux d'Afrique et d'autres régions du tiers monde. Mais surtout, dans cet essai, l'auteur se penche sur les possibles incidences politiques et sociojuridiques nationales, en Afrique et dans le tiers monde, de la mondialisation discrète dont la FIFA est un exemple et sur l'importance de l'intégration de cette préoccupation dans la mission universitaire de TWAIL.

\section{INTRODUCTION}

Sports are one field in international relations where global governance rules are being made, but apparently they are not being viewed or understood as in other fields. For many, it is difficult to see a connection between sports and global governance or international law for that matter. As the argument goes, there is a lot of politics involved in these fields which it would be desirable to distance sports from, lest they be contaminated. Nothing can be further from the truth. Sports are most of the time politics by other means and vice versa. ${ }^{3}$ And even if upon initial consideration one could accept the argument of the insulation of sports from politics, when the rule-making characteristics of certain sports governing bodies are closely examined, they show a strong presence of politics and popular social imagination. This essay discusses football as a sport with an autonomous set of regulations and shows how those regulations govern over national governments, especially those in the Third World.

The reluctance or inability of many to connect sports to the big political and governance issues of the day is nothing new. This fact is one that is very well known to Andrew Jennings, a British investigative journalist who has been reporting on the murky world of sports governance for several decades. In his words:

When I began investigating the IOC [International Olympic Committee] nearly 20 years ago some of my friends in journalism laughed: "Sport? We investigate governments, big business, the police. Why poke around in sport?' I said, 'Sports organizations are in the

3 See Aaron Beacom, "Sport in International Relations: A Case for Cross-Disciplinary Investigation” (2000) 20 Sports Historian 1; 
public sphere. They're backed by public money. They wield power. Why should they escape scrutiny?" And the gap I'd spotted between the Olympic limelight and its backrooms had piqued my curiosity with such force I could barely sleep at night. ${ }^{4}$

As Jennings would go on to show, what was true of the IOC held substantially or even more so for FIFA. Understanding how sports regulatory rules are developed in a way that has not been done before and using a framework never before used could provide new, critical insights into the current global governance discourse. Doing so from a TWAIL perspective in particular would no doubt illuminate hidden dangers of new global governance actors like FIFA.

The approach adopted in this paper is therefore sensitive to many of the core talking points of contemporary global governance, including the manner that it implicates, for example, the public/private divide. As is generally well known, current public law questions centre on the legitimacy of rules and the institutions making them, while in the context of private law those questions tend to be focused on functionality and problem-solving mechanisms. ${ }^{5}$ The paper is intended to not dwell too much on this dichotomy but to bridge the divide between what is public and what is private in relation to FIFA such that they are put in some form of healthy conversation.

Significantly, though it is embedded in FIFA's thought culture that sports and politics (domestic and international) are separate and should be kept so, this can no longer simply be assumed as some scholars have suggested. ${ }^{6}$ FIFA is an institution through which we can understand the challenge of fragmentation, the most complex "postmodern anxiety" of the contemporary international legal order. ${ }^{7}$ As Pielke Jr. asserts, accountability of FIFA matters for the governance of the sport, the business of football and the larger issue of the accountability of international organizations. ${ }^{8}$ It is his contention that "[t]he governance of FIFA is also a case study in the governance of international organizations, which includes a large class of governmental and non-governmental organizations that justify their legitimacy in terms of serving broadly shared interests. Effective governance of such institutions is thus a matter of common interest." 9

4 Andrew Jennings, "Investigating Corruption in Corporate Sport: The IOC and FIFA" (2011) 46 Intl Rev Sociology Sport 387 at 390. [Jennings, "Investigating"].

5 See e.g. Jaye Ellis, "Shades of Grey: Soft Law and the Validity of Public International Law" (2012) 25 Leiden J Intl L 313.

6 Paul Darby, Africa, Football and FIFA: Politics, Colonialism and Resistance (London: Frank Cass, 2002).

7 Martti Koskenniemi \& Paivi Leino, "Fragmentation of International Law? Postmodern Anxieties" (2005) 15 Leiden J Int'l L 553; Peer Zumbansen, "Transnational Legal Pluralism” (2010) 1 Transnat'l Leg Theory 141; Mario Prost, The Concept of Unity in Public International Law (Oxford: Hart Publishing, 2012); Kal Raustiala, "Institutional Proliferation and the International Legal Order" in Jeffrey Dunoff \& Mark Pollack eds, Interdisciplinary Perspectives on International Law and International Relations: The State of the Art (Cambridge: Cambridge University Press, 2012) 293; Paul S Berman, "From International Law to Law and Globalization" (2005) 43 Colum J Transnat'l L 485; Sahib Singh, "Two Potential Paths Forward from Fragmentation Discourse: Sociology and Ethics” (2011) 105 Proc. Ann Mtg (Am Soc'y Int'l L) 130; Volker Nerlich, "Why there is Nothing Wrong with 'Fragmentation' in International Criminal Procedures" (2013) 26 Leiden J Int'l L 777.

$8 \quad$ Roger Pielke Jr, "How can FIFA be held Accountable?" (2013) 16 Sport Mgt Rev 255 at 256.

9 Ibid. See also Mark Pieth, Governing FIFA: Concept Paper and Report (Geneva: FIFA, 2011), online: FIFA $<$ http://www.fifa.com/mm/document/affederation/footballgovernance/01/54/99/69/fifagutachten-en.pdf $>$. 
Without any doubt, FIFA's regulatory characteristics place it at the centre of one or the other of the various categorizations of the institutions of global governance. Yet, it has rarely been studied or discussed in the same breath as other transnational institutions even though, like all those other institutions, its activities exert considerable impact on the sovereignty of states. ${ }^{10}$ FIFA generates a range of norms similar to what is commonly understood to be "soft law" that not only regulate the game but also have great significance for transnational private governance. As will be discussed later, its statutes have in some jurisdictions been elevated to the position that treaties occupy in international law. FIFA members (states in the case of Africa) honour its regulatory norms often at the risk of severe sanctions that those states have little choice but to avoid.

There is obviously a great need to explore the imminence or otherwise (and indeed the desirability) of a transformation in critical Third World scholarship in response to the migration from international law to global governance. For example, keeping it focused on traditional approaches to international law (as in TWAIL above), this scholarship would advance towards approaches to global governance, that is Third World Approaches to Global Governance [TWAGG]. ${ }^{11}$ What this means is that, as the texture and architecture of the global system that TWAIL has critiqued for decades is changing, so must TWAIL itself and the scholars employing that framework. Where the focus used to be on states, the UN, its treaty-making bodies and other institutions like the International Court of Justice (as under traditional international law), that focus now must shift towards institutions of global governance such as FIFA and other emerging actors.

It is important at this point to state what this essay is not about. While it may have some degree of resonance with what is becoming known in recent times as global sports law or lex sportiva, this is not the focus of the essay. This will only take the essay towards answering the unresolved question of whether there is such concept as international sports law. As Foster notes, there is a difference between "international sports law" and "global sports law". 12 The difference is apparently founded on whether the system of law is autonomous and the extent that its regulatory reach implicates the sovereign lawmaking authority of states.

According to Foster, international sports law can be applied in domestic courts while the invocation of global sports law (which he calls lex sportiva) suggests immunity from national law and "a claim for non-intervention by both national legal systems and by international sports law". ${ }^{3}$ Given the autonomous and self-contained nature of FIFA regulations and the non-intervention requirements stipulated for affiliate federations that are described in greater detail later, its rules could qualify as lex sportiva in line with Foster's description. However, in recent times lex sportiva has been limited almost

10 See Darby, supra note 6; Andrew Jennings, Foul! The Secret World of FIFA: Bribes, Vote Rigging and Ticket Scandals (London: Harper Sport, 2006).

11 I owe my introduction to this concept to Prof. Anna Dolidze of the Faculty of Law, University of Western Ontario (on leave as Deputy Defence Minister in the Government of Georgia) who used it during her presentation " 12 Angry Scientists: Third World Approaches to International Law and Pugwash Conferences" (Fifth Annual Conference of the Toronto Group for the Study of International, Transnational and Comparative Law delivered at Osgoode Hall Law School, York University, 27-28 January 2012) [unpublished].

12 See Ken Foster, "Is there a Global Sports Law?" (2003) 2 Ent L 1.

13 Ibid at 2. 
exclusively to the work of the Court of Arbitration for Sports [CAS]. ${ }^{14}$ The CAS is presented as a functional mechanism for settling disputes arising in the field of sports in a very narrow sense that, if adopted in this essay, would not account for the ways in which FIFA rules encroach upon the sovereignty of states. In this way, this essay has an objective far broader than looking just at how international sports disputes are settled, to embrace as well how autonomous legal regimes such as FIFA's are redrawing the boundaries of transnational governance systems (including international law) in very significant ways.

\section{SITUATING TWAIL IN GLOBAL GOVERNANCE}

Two active terms start us off in this section. These are "TWAIL" and "global governance." How these two intersect form the thrust of the section. The idea is to conceptualize global governance and indicate how the TWAIL framework could inform its critique both at the level of praxis and in the character of the institutions driving it. What is global governance? What categories of institutions are active in the global governance context? How would TWAIL as a framework respond to global governance as practice? How could the framework enhance an understanding of this practice and the institutions propagating it from a Third World perspective?

Scholars who utilize TWAIL as critique are united by "a shared ethical commitment to the intellectual and practical struggle to expose, reform, or even retrench those features of the international legal system that help create or maintain the generally unequal, unfair, or unjust global order." 15 Gathii adds that a major theme of TWAIL scholarship is to build resistance towards projections of both metropolitan power and authority over Third World peoples - whether that power is military, economic, political, cultural or otherwise. ${ }^{16}$ The major concern here is with the cultural projection of metropolitan power through a sport that is played globally. This essay is therefore less concerned with other areas of TWAIL scholarship that may have been covered in existing scholarship.

Cultural power in this context stands for the proposition that the game of soccer or football represents a cultural category upon which the power and authority of the metropole exerts itself, sometimes in benign fashion, on the peoples of the Third World. While the projection of the military, economic and political metropolitan power and the impact this has on the Third World is fairly self-evident, how the cultural appropriation of sports like football in institutions of international governance hinders political and other choices in the Third World has received less attention. This is apparently for the simple reason that until fairly recently, such claims as to the cultural significance of certain sports provided limited ground for contestation. That may not still be the case after a 2012 statement attributed to Dave

14 See Lorenzo Casini, "The making of Lex Sportiva by the Court of Arbitration for Sport" (2011) 12 German LJ 1317; Allan Erbsen, "The Substance and Illusion of Lex Sportiva" in Robert Siekmann \& Janwillem Soek eds., The Court of Arbitration for Sport 1984-2004 (The Hague: Asser Press, 2012) 91; James AR Nafziger, “Lex Sportiva” (2004) 1-2 Intl Sports LJ 3.

15 Obiora Chinedu Okafor, "Newness, Imperialism, and International Legal Reform in our Time: A TWAIL Perspective" (2005) 43 Osgoode Hall LJ 171 at 176-177.

16 James Thuo Gathii, "TWAIL: A Brief History of its Origins, its Decentralized Network, and a Tentative Bibliography" (2011) 3 Trade L \& Dev 26 [Gathii, "History”]. 
Richards, then Chairman of the English Premier League (for which he later apologised), that FIFA stole the game from England. ${ }^{17}$ According to him,

England gave the world football. It gave the best legacy anyone could give. We gave them the game. For 50 years we owned the game ... We were the governance of the game. We wrote the rules, designed the pitches and everything else. Then, 50 years later, some guy came along and said: "You're liars," and they actually stole it. It was called FIFA. Fifty years later another gang came along called UEFA and stole a bit more. ${ }^{18}$

Recognizing that there must first be some basis for creating categories, of insiders and outsiders, of those whose interests are centred and those who are consigned to the margins, and of creating the "we" and the "other" binary within institutions before those categories could be institutionalized, might explain this attempt at cultural appropriation by England. It also could explain some of the game's more specific governance characteristics.

An example could be the International Football Association Board, which body is known as custodian of the rules of the game. It has only five members: the Football Associations of England, Scotland, Wales and Northern Ireland, as well as FIFA, which represents its other 204 member federations. ${ }^{19}$ Though FIFA has four votes on the Board and the others each have one vote, this does not cover for its apparent unrepresentativeness, especially for a sport of such global appeal; nor does the explanation for this skewed composition, which acknowledges "the historic significance of the British associations in world football." ${ }^{20}$ Apart from its cultural significance, there is also an economic dimension; Hobsbawm once said while describing football's economic footprint that it is "the child of Britain's global economic presence". ${ }^{21}$

For the present, it should be noted that certain trends have dominated the development of TWAIL as a framework for the critique of international law. ${ }^{22}$ The first trend was centred on how international law was deployed to justify colonialism and imperial power. ${ }^{23}$ The second trend shifted the focus towards understanding how hegemonic power politics was being institutionalized in new economic bodies

17 See Owen Gibson, "Sir Dave Richards says FIFA and UEFA stole Football from England," The Guardian (14 March 2012), online: <http://www.theguardian.com/football/2012/mar/14/dave-richards-fifa-uefa-stole-football >.

18 The acronym stands for the Union of European Football Associations, the governing body for the sport in the whole of Europe.

19 See FIFA “Form \& Function”, online: FIFA < http://www.fifa.com/mm/document/fifafacts/organisation/ip100_04e_ifab_9481.pdf>.

20 Ibid.

21 Eric Hobsbawm, Age of Extremes: The Short Twentieth Century 1914-1991 (London: Abacus, 1995$)$ at 198.

22 See Joyeeta Gupta, "Climate Change: A GAP Analysis based on Third World Approaches to International Law" (2010) 53 German YB Intl L 341 at 346.

23 Ibid. See also Antony Anghie, Imperialism, Sovereignty and the Making of International Law (Cambridge: Cambridge University Press, 2007); CL Lim, "Neither Sheep nor Peacocks: TO Elias and Post-Colonial International Law" (2008) 21 Leiden J Int'1 L 295; Luis Eslava \& Sundhya Pahuja, "Between Resistance and Reform: TWAIL and the Universality of International Law" (2011) 3 Trade L \& Dev 103. 
through international legal instruments. ${ }^{24}$ The final trend in TWAIL scholarship followed the 9/11 attacks in the United States and how the fight against terrorism was redrawing the boundaries of international law discourse. ${ }^{25}$ Because of the extent to which the regulatory activities of institutions like FIFA engage the behaviour of Third World states, it should not be out of place to imagine that TWAIL's fourth dimension in scholarship should already be in process.

TWAIL literature has aggregated around some common themes that are within the rubric of what I earlier referred to as traditional international law. Gathii, for example, mentions "public international law and international economic law"26 as areas that TWAIL scholarship had touched upon. Karin Mickelson not only identifies international economic law, but adds human rights and the environment as some of the themes that have driven TWAIL ideas. ${ }^{27}$ She specifically states that TWAIL scholars had been engaged in critique of an international economic system that marginalized the Third World and limited their ability to enjoy sovereign equality ${ }^{28}$ while also questioning the claimed universality of human rights. ${ }^{29}$

All this points to the possibility that TWAIL, as Gathii argues, is always open to exploring new areas. He has pointed to TWAIL's fluid architecture of complementary perspectives which allows individual scholars to "mix, reuse and re-combine" various ideas and themes. ${ }^{30}$ It will therefore suit a study of institutions like FIFA in its interactions with the governments, institutions and peoples of the Third World. While previous TWAIL analysis of international law and its institutions tended to dwell mostly on exclusion, discrimination and marginalization, an examination of FIFA using the same framework will not be restricted to these issues. It will in fact concern itself additionally with how FIFA's less than satisfactory governance praxis trickles down to the Third World through its domestic affiliated federations.

24 Ibid. See e.g. Ibironke Odumosu, "The Antinomies of the (Continued) Relevance of ICSID to the Third World" (2007) 8 San Diego Intl LJ 345; Ruth Gordon, "Contemplating the WTO from the Margins" (2006) 17 Berkeley La Raza L J 95; Balakrishnan Rajagopal, "From Resistance to Renewal: The Third World, Social Movements, and the Expansion of International Institutions" (2000) 41 Harv Int'1 L J 529; BS Chimni, “A Just World under Law: A View from the South" (2007) 22 Am U Intl L Rev 199 at 207; James Thuo Gathii, "Third World Approaches to International Economic Governance" in Richard Falk, Balakrishnan Rajagopal \& Jacqueline Stevens, eds, International Law and the Third World: Reshaping Justice (Oxford: Routledge-Cavendish, 2008) 255; BS Chimni, "Critical Theory and International Economic Law: A Third World Approach to International Law (TWAIL) Perspective" in John Linarelli ed, Research Handbook on Global Justice and International Economic Law (Cheltenham: Edward Elgar Publishing Ltd, 2013$) 251$.

25 Ibid. See also Madhav Khosla, “The TWAIL Discourse: The Emergence of a New Phase” (2007) 9 Int'l Comm L Rev 291; Upendra Baxi, “The 'War on Terror' and the 'War of Terror': Nomadic Multitudes, Aggressive Incumbents, and the 'New' International Law: Prefatory Remarks on Two 'Wars"” (2005) 43 Osgoode Hall LJ 7; Antony Anghie, "The War on Terror and Iraq in Historical Perspective" (2005) 43 Osgoode Hall LJ 45; Usha Natarajan, "A Third World Approach to Debating the Legality of the Iraq War" (2007) 9 Intl Comm L Rev 405.

26 Gathii, "History", supra note 16 at 29.

27 Karin Mickelson, "Taking Stock of TWAIL Histories" (2008) 10 Intl Comm L Rev 355; Karin Mickelson, "Rhetoric and Rage: Third World Voices in International Legal Discourse" (1998) 16 Wisc Intl LJ 353 [Mickelson, "Rhetoric and Rage"].

28 Mickelson, "Rhetoric and Rage", ibid, at 363.

29 Ibid at 374.

30 Gathii, "History", supra note 16 at 37. Another scholar sees TWAIL as more "a chorus of voices" rather than a simple monolithic collegium: see Okafor, supra note 16 at 176; see also Mickelson, Rhetoric and Rage, supra note 27 at 360. 
The second leg of this conceptual background focuses on the subject of global governance, FIFA's role in it and how/why this should be of concern to Third World countries. In recent years, international law scholarship highlights a "new orthodoxy" which goes beyond the traditional focus on states as the basic actors and creators of law. ${ }^{31}$ Outside the state under this unfolding paradigm, new international actors have broken out in large numbers. Their rule-creating and regulatory capacities tend, by some accounts, to render the state out of fashion or at least out of focus ${ }^{32}$ and in that sense limit the autonomy of states. $^{33}$

International institutions today occupy a dense and fragmented field, dispersing complex normative arrangements across a range of thematic areas. Some see these institutions as prescribing norms of transnational $\mathrm{law}^{34}$ or regulating various governmental and non-governmental networks or indeed exporting judicial models through transplantation and cooperation across borders. ${ }^{35}$ It is interesting that in one of the major categorizations FIFA was actually mentioned as a professional body and one of the major global governance institutions operating in contemporary times. ${ }^{36}$

Regarding the normative rules prevalent in the global governance domain, some of them are produced by institutions engaged in what has been described as "private' global norm production",37, capturing codes of conduct ranging from corporate social or environmental responsibility ${ }^{38}$ to rules of standardization and other types of self-regulation. ${ }^{39}$ Or, they could be in the nature of "soft law",

31 Yves Dezalay \& Bryant Garth eds, Global Perspectives: The Production, Exportation, and Importation of a New Orthodoxy (Ann Arbor: University of Michigan Press, 2002); Anne Marie Slaughter, "Breaking Out: The Proliferation of Actors in the International System" in Dezalay \& Garth, supra note 31, 12 at 15; Serge Sur, "The State between Fragmentation and Globalization" (1997) 3 Eur J Intl L 421.

32 Slaughter, ibid; see also Nakatani Yoshikazu, "State and Democracy Besieged by Globalization" (2010) 7 Ritsumeikan L Rev 1 at 4; Berman, supra note 7.

33 Bhupinder S Chimni, "International Institutions Today: An Imperial Global State in the Making" (2004) Eur J Intl L 1; Ulrich Muckenberger, "Civilising Globalism: Transnational Norm-Building Networks as a Lever of the Emerging Global Legal Order" (2010) Transnat'1 Legal Theory 523; Jeremy Rabkin, "Recalling the Case for Sovereignty" (2005) 5 Chicago J Intl L 435; Jeremy Rabkin, "National Sovereignty in a Globalising World”, online:

$<$ http://aphnew.aph.gov.au/binaries/senate/pubs/pops/pop38/rabkin.pdf>; Julian Ku \& John Yoo, "Globalization and Sovereignty" (2013) 31 Berkeley J Int'1 L 210.

34 See Philip Jessup, Transnational Law (New Haven: Yale University Press, 1950) at 2: "I shall use instead of 'International Law'; the term 'transnational law' to include all law which regulates actions or events that transcend national frontiers. Both public and private international law are included, as are other rules which do not wholly fit into such standard categories." See also Peer Zumbansen, "Transnational Law" in Jan Smits ed, Encyclopedia of Comparative Law (Cheltenham: Edward Elgar Publishing, 2006) 738; Craig Scott, "Transnational Law as ProtoConcept: Three Conceptions" (2009) 10 German LJ 859.

35 Berman, supra note 7.

36 Richard Bellamy \& RJ Barry Jones, "Globalization and Democracy - an Afterword” in Barry Holden, ed Global Democracy: Key Debates (London: Routledge, 2000) 202 at 204.

37 Gunther Teubner, "Breaking Frames: The Global Interplay of Legal and Social Systems" (1997) 45 Am J Comp L 149 at 157; Jan Smits, Private Law 2.0: On the Role of Private Actors in a Post-National Society (The Hague: Eleven International Publishing, 2011) online: $<$ http://www.hiil.org/data/sitemanagement/media/Publication_Smits_250211.pdf $>$.

38 Smits, supra note 37 at 8.

39 Ibid. 
examples of which could be the Draft Common Frame of Reference of European Private Law, ${ }^{40}$ the Framework for Conflict Prevention of the Economic Community of West African States, ${ }^{41}$ or the Kimberley Process for the certification of diamonds traded at the international market place. $^{42}$

The interaction of institutions and norms in this context illustrates the development of what is better known today as "global governance", defined as "purposeful activity intended to 'control' or influence someone else that either occurs in the arena occupied by nations or, occurring at other levels, projects influence into that arena." $\mathrm{It}$ is the governing (without sovereign authority) of "relationships that transcend national frontiers..., [it is] doing internationally what governments do at home."44 There is recognition that the international system is experiencing a progression from government to governance, ${ }^{45}$ though some scholars argue that this does not in any way signal the displacement of the state in international governance. ${ }^{46}$ And while commentators define governance in diverse and often maddeningly imprecise ways, according to Bellamy and Jones, all of them focus on a common phenomenon; namely, the expansion of regulatory and decision-making mechanisms beyond the various branches of the state and away from formal and hierarchically ordered structures of authority. ${ }^{47}$

\section{FIFA AS A GLOBAL GOVERNANCE ACTOR}

FIFA's significance as a global governance institution has a lot to do with how its regulatory actions affect sovereign states and burden their choices. As a basic starting position, therefore, it qualifies as an international organization. It could also fit in other descriptions as a formal or informal transgovernmental network, a hybrid public-private institutional arrangement, or an entirely private

40 Christian Von Bar \& Eric Clive eds, Principles, Definitions, and Model Rules of European Private Law: Draft Common Frame of Reference (Munich: Sellier European Law Publishers, 2009), online:

$<$ https://www.law.kuleuven.be/personal/mstorme/2009_02_DCFR_OutlineEdition.pdf $>$.

41 See Kehinde Bolaji, “Adapting Traditional Peacemaking Principles to Contemporary Conflicts: The ECOWAS Conflict Prevention Framework" (2011) 1 Afr Conflict \& Peacebuilding Rev 183; Poorneema Devi Bujun, Martial Foucault \& Frederic Merand, "Regional Security Governance and Collective Action" in James Sperling ed, Handbook of Governance and Security (Cheltenham: Edward Elgar, 2014) 289 at 298.

42 See Clive Wright, "Tackling Conflict Diamonds: The Kimberley Process Certification Scheme" (2004) 11 Int'1 Peacekeeping 697; Virginia Haufler, "The Kimberley Process Certification Scheme: An Innovation in Global Governance and Conflict Prevention (2009) 89 J Bus Ethics 403; Julie Fishman, "Is Diamond Smuggling Forever? The Kimberley Process Certification Scheme: The First Step Down the Long Road to Solving the Blood Diamond Trade Problem" (2005) 13 U Miami Bus L Rev 217.

43 Lawrence S Finkelstein, "What is Global Governance?" (1995) 1 Global Governance 367 at 368.

44 Ibid at 369.

45 Bellamy \& Jones, supra note 36 at 204.

46 See e g, Saskia Sassen, "Neither Global nor National: Novel Assemblages of Territory, Authority and Rights" (2008) 1 Ethics \& Global Politics 61 at 62 stating that "Their [private transnational actors') proliferation does not represent the end of national states, but it does begin to disassemble the national"; Saskia Sassen, "Globalization or Denationalization?" (2003) 10 Rev Int'1 Pol Econ 1 at 6; Saskia Sassen, "The Participation of States and Citizens in Global Governance" (2003) 10 Ind J Global Leg Stud 5.

47 Bellamy \& Jones, supra note 36. 
transnational institution. ${ }^{48}$ As will be explained later, FIFA is registered as a quasi-charity under Swiss civil law, which could be misleading in the context of its earlier characteristics described above.

Aside from these labels, we must also consider the magnitude of what FIFA does internationally. Very few sports, if any, can rival football in terms of its mass cultural appeal and global popularity. FIFA, utilizing this global appeal, has earned extraordinary commercial successes even though it pays little or no taxes at all. ${ }^{49}$ It leverages the power of the sport in a profound way and could use it as a force for public good. Yet FIFA is as comfortable interacting with the most brutal dictators as it is dealing with the most democratic of regimes. In terms of plain numbers, FIFA has more member states (208) than the United Nations (192).

Though it is registered as a non-governmental institution in Switzerland, its control of football makes it a significant private body with substantial transnational powers. Its affiliate national federations, especially those in Africa, do not share FIFA's non-governmental character. As is shown later in this essay, many of those federations are established by domestic laws and are significantly funded by the government. $^{50}$ Therefore, while it is a global game and FIFA often conveys the impression that its governance rules and institutions are uniform across the world's regions, the reality is clearly opposed to any such assumption.

As Chimni notes, international law and the international governance system to which FIFA belongs often prescribes rules "that deliberately ignore the phenomena of uneven development in favour of prescribing uniform global standards." As will be made clear in this essay, when it is convenient or expedient to those who formulate the rules for this unfair system, they enforce difference in a way that renders pretentious the measures they prescribe to justify this uniformity. But. more often than not, they don't even affect such pretentions; they go for good old discrimination and "othering". A clear example of this would be in the discriminatory rules FIFA prescribes for the host countries of its flagship tournament, the World Cup. Two examples easily come to mind in this regard: South Africa hosting the 2010 tournament and Brazil hosting the same event in 2014. On each of these occasions, FIFA used its awesome powers to cause substantial changes to the legal regimes of both countries. It did so in a manner that it had not done to any of the previous host nations in the global North.

In preparation for the 2010 tournament, for example, while battling unjustified doubts as to its ability to be an effective host, ${ }^{52}$ the South African Parliament passed Special Measures Acts 11 and 12 targeted to ensure that the country completed projects it had promised FIFA beforehand that it would complete.

48 See Walter Mattli \& Tim Buthe, "Global Private Governance: Lessons from a National Model of Setting Standards in Accounting” (2005) 68 Law \& Contemp Prob 225.

49 FIFA's income for 2014 alone was US\$5.7 billion; see Gigi Alford \& Sam Dupont, "Why FIFA’s Strongman is a Bad Role Model for the World: FIFA's Imperious President, Sepp Blatter, is poised to win a Fifth Term using the Playbook of the World's Slickest Dictators" Foreign Policy (20 May 2015), online: Foreign Policy $<$ https://foreignpolicy.com/2015/05/20/why-soccers-strongman-is-a-bad-role-model-for-the-world-fifa-sepp-blatter/>.

50 The Nigeria Football Association (before its extra-legislative change of name to the Nigeria Football Federation) Act of 1992.

$51 \quad$ BS Chimni, "Third World Approaches to International Law: A Manifesto" (2006) 8 Intl Comm L Rev 3 at 5.

52 See Luke Harding, "Doubts Over South Africa 2010" The Guardian (12 July 2006), online: $<$ http://www.theguardian.com/football/2006/jul/12/newsstory.sport1 $>$. 
As well, for the duration of the tournament, South Africa suspended some of its constitutional rights. Critics argued this was to satisfy FIFA sponsors and advertisers and thus protect its cash cow. ${ }^{53}$

In addition to the legislative changes implemented at FIFA's behest, South Africa also created up to 56 courts specifically for the FIFA World Cup, a move unprecedented in the history of the tournament. ${ }^{54}$ The courts were staffed with 1,500 personnel, including magistrates, prosecutors, public defenders, and interpreters, and had jurisdiction over all crimes arising out of the World Cup tournament. ${ }^{55}$ These courts had an expedited trial process, in contrast to South Africa's normal court system, in which there could be substantial delays. One particular case involved two Zimbabweans accused of robbing a foreign journalist. They were accused on a Wednesday and arrested the next day, Thursday. Both stood trial and then began 15-year jail sentences on Friday. ${ }^{56}$

Such was also the case for the 2014 World Cup when FIFA stipulated that Brazil, while hosting the World Cup, must allow the sale of alcohol at stadiums. Under a 2003 Brazilian law, alcohol consumption at sporting event stadiums was prohibited because of the high number of fans being killed at games. ${ }^{57}$ Brazil succumbed to FIFA pressure and so passed the so-called "Budweiser Bill," 58 named after one of FIFA's major sponsors whose main business is the production and sale of beer. In other words, rather than be sensitive to the security implications of this act given Brazil's peculiar security concerns, FIFA focused more on its commercial objectives.

Yet Brazil had to provide a different guarantee to the effect that the Brazilian Government assumed liability for any safety issues from the tournament. While FIFA had near total control of the tournament, the guarantee was that the Brazilians, and not FIFA, would bear civil liability for damages arising from any safety-related accident in connection with the tournament. FIFA also contracted to create an area around the tournament venues where only FIFA and its partners had rights to advertise and sell products and services. ${ }^{59}$ In contrast, for the 2006 tournament that Germany hosted, the security strategy did not involve any major legislative overhauls. As the organizers pointed out, all they did was to ensure that

53 See Kathleen Tang, "The World Cup: Changing Country’s Laws, One Tournament at a Time” (2013) Travaux: The Berkeley J Int'l L Blog, online: < http://berkeleytravaux.com/world-cup-changing-countrys-laws-one-tournament-time/>.

54 Richard George \& Kamilla Swart, "International Tourists' Perceptions of Crime-Risk and Future Travel Intentions during the 2010 World Cup in South Africa" (2012) 17 J Sport \& Tourism 201.

55 See Tang, supra note 53.

56 Ibid.

57 Ibid.

58 John Oliver, "Last Week Tonight with John Oliver: FIFA and the World Cup", online: YouTube $<$ https://www.youtube.com/watch?v=D1JEt2KU33I $>$. It would be interesting how FIFA intends to negotiate this requirement in the case of Qatar, the host country for its 2022 World Cup, which is governed under an Islamic monarchy. That suggests that alcohol consumption may not pass as easily there as was the case in Brazil. See for example Cork Gaines, "Qatar Vows to be 'Creative' with Alcohol at 2022 World Cup but Offers no Guarantees" Business Insider, (11 November 2014) online: <http://www.businessinsider.com/qatar-alcohol-gay-fans-world-cup2014-11>. The country also has very strict anti-gay laws. And Blatter's advice to gays who intend to be at the World Cup in Qatar is that they should not engage in any sexual activity; see "FIFA Boss Sepp Blatter Sparks Qatar Gay 59 Ibid 
"[p]otential trouble makers were specifically warned, certain individuals were required to report to the police or banned from entering inner cities or stadium areas." 60

\section{IS FIFA A PUBLIC OR PRIVATE ORGANIZATION?}

It is very likely that one of the major reasons FIFA's regulatory and governance activities have elicited less academic scrutiny qua global governance institution is because of the difficulty in pinning it down as either a private or public entity. There is only one reason it is important to answer this question in the context of this article. FIFA most probably would not qualify for this kind of evaluation if its activities were not of such a nature as to invade the sphere traditionally occupied by governments, and especially those in the Third World. Yet this is essentially what happens in practice, such that it is unclear whether or not it is a public or private entity. The same question arises with different kinds of contextual strictures when attention is turned to its affiliate local federations.

Reference was made earlier to FIFA's understanding of its own legal status under Swiss law as a nongovernmental entity. It is registered in the commercial register in accordance with Article $60 \mathrm{ff}$. of the Swiss Civil Code, which deals with "Associations". Associations registered under this Article could have political, religious, scientific, cultural, charitable, social or other non-commercial purposes and acquire legal personality once their intention to exist as a corporate body is shown in their articles of association. ${ }^{61}$ In the latest iteration of its Statutes, one of FIFA's stated core objectives is "to improve the game of football constantly and promote it globally in the light of its unifying, educational, cultural and humanitarian values, particularly through youth and development programmes..." ${ }^{62}$ This status in reality only "guarantees minimal disclosure about what [FIFA] do with the money. But they make a lot of noise about their commitment to transparency". ${ }^{3}$

Taken on its face value, this could qualify FIFA as only a private charity. But on a deeper assessment of its actual governance methods, it cannot be denied that FIFA's public activities and their consequences offer substantial evidence that it is not just a non-governmental entity pursuing some charitable causes. For example, in organizing its tournaments, it encroaches far too deeply into public territory $^{64}$ through the hosting procedures and requirements that it prescribes for the host nations. FIFA therefore essentially straddles the public and private divide depending on the context. In some regards, it functions like a private entity with its own funds empowering it to push against government interference.

60 See, It Truly was a Time to make Friends: Review by the Federal Government on the 2006 World Cup (Berlin: Federal Ministry of the Interior, 2006) at 8, online: Die Bundesregierung $<\mathrm{http}: / / \mathrm{wm} 2006$.deutsch-

land.de/EN/Content/SharedDocs/Downloads/world-cup-review,property=publicationFile.pdf $>$.

61 Allan Tomlinson, FIFA (Federation Internationale de Football Association): The Men, the Myths and the Money (Oxford: Routledge, 2014) at 28.

62 See FIFA Statutes: Regulation Governing the Application of the Statutes Standing Orders of the Congress, April 2015 adopted at the 64th Congress of FIFA held in Sao Paolo, Brazil, 11 June 2014 and came into force on 1 April 2015 at 6, online: FIFA Statutes

$<$ http://resources.fifa.com/mm/document/affederation/generic/02/58/14/48/2015fifastatutesen_neutral.pdf > .

63 See Jennings, "Investigating", supra note 4 at 395 (emphasis added).

64 Claire Cutler, Virginia Haufler \& Tony Porter, Private Authority and International Affairs" in Claire Cutler, Virginia Haufler \& Tony Porter eds, Private Authority and International Affairs (Albany: SUNY Press, 1999) at 16. 
It is also a public entity to the extent (as will be shown below) that it influences and sometimes outrightly dictates domestic laws.

As an example, its standard cooperation agreements with host nations for its competitions are mostly signed with governments while the domestic affiliate associations occupy a less prominent (it seems) place in such agreements. These agreements themselves cover various government functions, from providing finance to security, certification of football facilities and international relations. And, given the levels of commitment demanded in these areas, it is inconceivable that these activities would not have serious impacts on government business.

Notably, FIFA's claim to non-governmental status has not, at least in the African context, translated to automatic non-governmental character for its affiliate national federations in the same manner. Take the Nigeria Football Association [FA] (or Federation, if you will) for example. The last edition of the law establishing it is Act No. 110, which itself is undergoing repeal and re-promulgation before the Nigeria National Assembly. ${ }^{65}$ This Act in turn repealed the military-decreed legislation no. 101 of 1992 , under which the association had been governed up to that period. Section 1(1) of Act 110 provides that "[t]here is hereby established an association to be known as the Nigeria Football Association," which under subsection (2)(a) \& (b) "shall be a body corporate with perpetual succession and a common seal...and may sue and be sued in its corporate name." This is standard establishment provisions for all government agencies/departments (or in standard local parlance, "parastatals") in Nigeria.

This provision raises at least one important question. How is it possible that a government could promulgate a private "association" into existence? In most legal systems, associations are brought to life first by like-minded individuals pursuing clearly stated goals. These individuals would then seek legal recognition for their association under the relevant legal regime. As such, for the Nigerian football federation to be actually non-governmental in the sense of FIFA, it had to be established as similar associations are under Nigeria's Company and Allied Matters Act. In that case, rather than the current situation where the government seems to control its very existence from establishment to management, it would be up to interested individuals to band together in the tradition of all such voluntary bodies and decide what legal status suits their objectives.

It is, however, understandable why the Nigerian football federation and similar bodies in Africa have heavy government involvement in their establishment and management. Under Act 110, for example, the Minister for Sports in Nigeria (who in most cases is a politician put in office by the government of the day) appoints the Secretary General of the FA who is its chief executive officer. ${ }^{66}$ The remuneration, tenure of office and conditions of service of the Secretary General and the FA's other employees are fixed according to Federal Civil Service Rules and Regulations applicable to other staff of the Federal Ministry of Sports. ${ }^{67}$ Furthermore, although it could raise its own funds through charges, fees, dues, interests, donations, grants-in-aid and endowments, the FA relies more on grants from the Federal Government for its activities than from these other sources. ${ }^{68}$

\footnotetext{
65 See the Nigerian Football Association Act Cap No. 110 LFN 2004 (Repeal and Re-Enactment) Bill 2014.

66 Ibid, section 13(1).

67 Ibid, section 13(4).

68 Ibid, section 15.
} 
A visit to the FIFA headquarters in 2012 by then Nigerian Sports Minister, Bolaji Abdullahi, to discuss yet another impasse in the management of the game in Nigeria clearly illustrates the extent of government involvement in the game. FIFA officials, according to reports, were left stunned when the Minister informed them that the Nigerian government provides grants in excess of 20 million United States dollars annually to the FA. ${ }^{69}$ As the Minister narrated:

We showed evidence of the annual budget for Nigeria football and it was converted to dollars at their request. It turned out to be about $\$ 25 \mathrm{~m}$ which was shocking to them. Their understanding was that it was minimal support which was why they had always taken certain position. [sic]. But it was clear that no government will give that amount to any group and then not ask if the money was judiciously used. We should not mix the demand for accountability with interference. There has to be oversight supervision to certain levels. $^{70}$

This figure could be significantly higher in years that Nigeria has to participate in big FIFA tournaments like the World Cup or the African Nations Cup. Government financial intervention is called for to participate in these tournaments mostly because advertising and sponsorship revenues for the FA pale in comparison to the actual funds needed for effective participation in them.

The problem, however, is that despite its financial commitments and legal ties to the very existence of the FA, the Nigerian government cannot request accountability from the game's domestic administrators without FIFA intervening from Zurich on the grounds that government cannot interfere in the management of the sport. This much is clear from the Minister's story above. For many African governments, this is a catalyst for constant friction with FIFA and has led to various incidences of bans and suspensions of their football associations for what FIFA describes broadly as government interference.

Between 2010 and 2013, FIFA threatened the football associations of Cameroon, ${ }^{71}$ Sierra Leone, ${ }^{72}$ Kenya, ${ }^{73}$ Uganda $^{74}$ Egypt $^{75}$ and Nigeria ${ }^{76}$ with bans for varying reasons. Its definition of interference is

69 See Ezeocha Nzeh, "Nigeria’s Annual \$20m Grant to NFF Shocks FIFA” The Guardian (16 March 2012), online: $<$ http://odili.net/news/source/2012/mar/16/8.html>.

70 See Pius Ayinor, "Only Embedded Autonomy for NFF" The Punch, 22 March 2012 (copy on file with the author).

71 Leocadia Bongben, "Fifa lifts a global ban on Cameroon for government interference" BBC Sport (22 July 2013), online: $<$ http://www.bbc.com/sport/0/football/23405627>.

72 Mohamed Fajah Barrie, "Fifa intervenes in long-running Sierra Leone dispute" BBC Sport (20 December 2011), online: $<$ http://www.bbc.com/sport/0/football/16267424>; see also Mohamed Fajah Barrie, "Fifa Endorses Decision to Ban Kallon from SLFA Election” BBC Sport (2 August 2013), online: <http://www.bbc.com/sport/0/football/23549250>.

73 See "Kenya FA under Investigation by Anti-Corruption Agency" BBC Sport (26 July 2013) online: $<$ http://www.bbc.com/sport/0/football/23464557?ocid=socialflow_twitter_africa $>$.

74 Andrew Jackson Oryada "Fifa Issues Ban Warning to Uganda" BBC Sport (22 July 2013) online: $<$ http://www.bbc.com/sport/0/football/23405632>.

75 ESPN Soccernet Staff, "Blatter looks to Reinstate Egypt FA" ESPN FC (6 February 2012), online: $<$ http://www.espnfc.com/story/1018437/fifa-president-sepp-blatter-looks-to-reinstate-egypt-fa $>$. 
a very convenient one that can be mystifying to African governments. In Uganda's case, for example, the government claimed the country's football federation was being operated as a private company in a manner that is not consistent with Ugandan law. ${ }^{77}$ This explanation did not seem to have impressed FIFA. With regard to Cameroon, in 2013 Iya Mohamed was elected to head their federation (FECAFOOT) though he was in detention for alleged embezzlement of funds. His election was later voided by FIFA's intervention on grounds of government interference. ${ }^{78}$ More examples could be given with some classic instances coming from Nigeria.

After the 2010 World Cup tournament in South Africa where her team performed woefully, the Nigerian government dissolved the national team and instituted a two-year break from all international soccer competitions. ${ }^{79}$ The government said the time would be spent reorganizing the game in the country. FIFA quickly issued a warning, threatening to ban the country. ${ }^{80}$ The Nigerian government later caved into the pressure and lifted the suspension without offering any justification for its changed stance. In 2014, the Nigerian government through the Ministry of Sports demanded accountability from the football federation for the funds the government provided for the administration of the game during the year. ${ }^{81}$ It also coincided with the termination of the tenure of the then FA leadership and arrest of some of them for alleged fraud. FIFA immediately accused the Nigerian government of meddling and banned the country from all international competitions. ${ }^{82}$ The ban was lifted about a week later after the government reinstated the sacked officials. ${ }^{83}$

To be sure, FIFA has had almost identical squabbles with the football federations of Greece, Spain and Poland. ${ }^{84}$ In the Greek case, in 1993, the government introduced legislation to address the fixing of games among other vices threatening the game. The Greek federation did not like the proposal and cried to FIFA. Its threat to suspend the country arrived swiftly and would, if it had been implemented, have excluded the country from the 1994 World Cup. The government withdrew the proposed law. It tried again in 1999 to tighten domestic control of the sport but for the second time capitulated to FIFA's

76 See Telegraph Staff \& Agencies, “World Cup 2010: FIFA Threatens Nigeria with Ban over Team's Suspension” The Telegraph (2 July 2010), online: <http://www.telegraph.co.uk/sport/football/teams/nigeria/7867686/World-Cup-2010Fifa-threatens-Nigeria-with-ban-over-teams-suspension.html>.

77 ESPN Soccernet Staff, supra note 75.

78 Bongben, supra note 71.

79 See "World Cup 2010: Nigerian President suspends Team" BBC Sport (30 June 2010), online: $<$ http://news.bbc.co.uk/sport2/hi/football/world_cup_2010/8777118.stm>.

80 "World Cup 2010: FIFA threatens Nigeria with Ban over Team's Suspension" The Telegraph (2 July 2010), online: $<$ http://www.telegraph.co.uk/sport/football/teams/nigeria/7867686/World-Cup-2010-Fifa-threatens-Nigeria-with-banover-teams-suspension.html>.

81 See "FG Demands N2.591B Account from NFF" The Nation, 8 July 2014, online: <http://thenationonline-ng.net/fgdemands-n2-591b-account-from-nff/>.

82 "FIFA Bans Nigeria from International Football" CNN, 10 July 2014, online: <http://edition.cnn.com/2014/07/10/sport/football/football-nigeria-fifa-banned/>.

83 "Nigeria's Ban from FIFA Lifted after Reinstatement of Officials" The Guardian (18 July 2014), online: $<$ http://www.theguardian.com/football/2014/jul/18/nigeria-reinstated-fifa-ban>.

84 B Garcia \& HE Meier, "Keeping Private Governance Private: Is FIFA Blackmailing National Governments?" (Paper delivered at the EUSA Biennial Conference, Baltimore, Maryland, 9-11 May 2013), online: $<$ https://dspace.lboro.ac.uk/dspace-jspui/bitstream/2134/12635/3/Keeping\%20private\%20governance\%20private_paper_eusa_BG.pdf>. 
threats. In 2006, the government went all the way by changing the rules for electing the federation president. This time FIFA suspended the federation. And yet again the government caved in to "overwhelming [domestic] social and political pressure" in addition to that from FIFA. ${ }^{85}$

\section{TROUBLING JURISPRUDENCE FROM DOMESTIC COURTS}

More than the above blurred vision of FIFA as either public or private and the constraints this places on domestic political governance, the organization is also being accorded substantial governance status in some domestic legal systems. Though it is unclear whether its regulations could attract uniform normative weight in various legal regimes, there are interpretations in some jurisdictions that confer extraordinary legal significance to an institution that suffers from various governance shortcomings, as highlighted across the different sections of this article. There is growing awareness that the status given to FIFA's regulations could confer upon it legal authority similar to that enjoyed by states in international law. An example is a case that arose in Nigeria in 2010 in which one of the questions that the court had to answer was to the nature of the Confederation of Africa Football [CAF] Statute 20002004. ${ }^{86}$ One of the parties claimed that this statute removed the power of the courts in Nigeria (including the present one) to hear cases dealing with its application.

The facts of the case were that the appellant commenced action claiming that the Executive Committee of the Nigeria Referees Association [NRA] was disqualified from conducting its own election because it had a vested interest in the outcome. The appellant also alleged bias on the part of the NRA, which rendered it incapable of organizing a free or fair election. Specifically, he argued that guidelines issued for the election breached the principles of natural justice and fair hearing as they made the NRA Electoral Committee a judge in its own cause. He therefore called on the Nigerian FA to establish an independent body to conduct the election.

The responding parties asserted that the NRA was not a legal entity and therefore could not be sued. They also argued that the statute of the NRA precluded it from being sued in relation to the administration of football referees in Nigeria. Besides, they claimed that the appellant lacked legal standing to bring the suit as he had not been nominated for the election in question and had not paid fees prescribed under the electoral guidelines. One of the questions that the court had to answer was: what is the nature of the Statute of the CAF 2000-2004 which the responding parties claimed ousted the power of the court to hear the case? The first instance court dismissed it, leading to this appeal.

While what was at stake in the case was the Statute of the CAF, the appeal court premised its reasoning on section 12(1) of the Constitution of the Federal Republic of Nigeria, 1999, which provides that no treaty between Nigeria and any other country shall have force of law except to the extent to which such a treaty has been enacted into law by the Nigerian National Assembly. Judge Aboki, who wrote the judgment of the court's plurality, ruled that the court lacked power to apply or even "construe" a treaty that is not yet translated to domestic law and that its provisions cannot have effect on the rights and duties of citizens. He then declared that the first instance court committed a legal error when it

$85 \quad$ Ibid at 13.

86 Ray Nnaji v Nigeria Football Association \& Ahmed Maude, Representing All Members of the Nigeria Referees Association [2010] 11 NWLR (Pt 1206) 438. 
relied on the provisions of the CAF Statute 2000-2004, which had not been incorporated into Nigeria's domestic laws. ${ }^{87}$

Though this case involved not the FIFA Statutes but those of the African body, the way the Court of Appeal answered the main question before it has clear extrapolatory significance in relation to the status of FIFA's own statutes in Nigeria's domestic legal regime. It can safely be argued that the court would have adopted the same reasoning if it had to interpret the FIFA Statutes rather than those of CAF. That is not to say that the court's reasoning is without significant shortcomings given that all it accomplishes is to further complicate the public/private confusion regarding FIFA. It does so by placing both FIFA and CAF on the same pedestal as sovereign states, which it is unlikely FIFA itself will agree with. This is so because if FIFA has the status of a state, it cannot at the same time also be a private legal entity.

It is unlikely that CAF or FIFA will agree that they have the same status in international law as states or that their statutes have the same implications as treaties agreed by states. How the court in the case above came to the conclusion it reached is hard to explain. The only institution in the country involved as party to both CAF and FIFA statutes is the Nigerian football federation which, if FIFA's own understanding of its status is any indication, is a private body comprised of individuals interested in the game of football. They do not represent the Nigerian state in treaty making capacity any more than the same could be said about Nigerian agencies that participate in the activities of other private international organizations.

The lack of clarity in FIFA's status as an international organization has only fueled schisms between the transnational and domestic contexts. The impact of the disagreements has not been uniform across all the world's geographic regions. There is less of an impact in regions where the game is organized along FIFA's preferred structure of private governance with minimal government intrusion. In those regions, government funding of the game is insignificant, if at all. Things are different in Third World countries where there is less sponsorship and advertising revenue such that governments tend to fund the game substantially. And, often those governments look for control of the game that is commensurate to the level of funding they provide. This brings them in constant collision with FIFA as already noted, which rubs off negatively on the domestic game.

It is unlikely the question whether FIFA is public or private can be resolved by simply looking at its legal status under Swiss law or by analyzing its relationship with governments in isolation. But the complexity feeds other inappropriate governance practices that FIFA has come to embody in more recent times. The fact that there is no institution or structure that could bring FIFA to the accountability table at the moment has therefore only abetted its rejection of due process as well as the misuse of its regulatory powers in mediating the relationship between governments and domestic football associations. The following subsections exemplify some of the governance deficits bedevilling FIFA and the repercussions they might bring with them to the Third World. These include endemic corruption, life term dictatorial tendencies and power impunity.

\footnotetext{
${ }^{87}$ Ibid at 441.
} 


\section{FIFA SPREADING CORRUPTION LIKE A VIRUS}

FIFA and African governments often accuse one another of interference in their affairs. It is becoming clearly evident that FIFA perhaps interferes more in the way African governments run their countries than otherwise. In doing so, it uses the popularity of the game and its enormous sponsorship and advertising resources as leverage. Sepp Blatter in particular, throughout his term as FIFA President, distributed its revenue funds in a manner that none of his predecessors ever did. This has implications for the prevalence of corruption which is one of the major governance deficits that bedevils FIFA and the damaging impact this has in a Third World context.

FIFA seems to operate a governance model that renders it incapable of instituting accountability either of its own activities or those of its affiliate associations. This in turn produces a number of sociopolitical and economic problems, one of which is endemic corruption within it as a body and spreading to its affiliates. To some, FIFA sits on a dome of corruption that was once hidden in secrecy but has since spilled into the open over the last couple of years. ${ }^{88}$ Because corruption is generally more of an intractable problem and its consequences more devastating in the Third World than in developed countries, FIFA's failings in this regard more likely than not would enable a huge empire of graft in societies where this problem is most endemic.

In recent years, FIFA's image has been tarnished by recurring incidents of corruption, which has seen it stumble from one scandal to another. ${ }^{89}$ In July 2012, Sepp Blatter, then FIFA's president, spoke about "rotten eggs" in its executive committee but said he was powerless to prevent them entering the body. ${ }^{90}$ In the same year and month, court documents that FIFA made public showed that its two former officials, Joao Havelange and Ricardo Teixeira allegedly took millions of pounds in bribes from ISL, FIFA's marketing partners. The company collapsed in 2001, leaving behind debts of over $\$ 300$ million. ${ }^{91}$ Havelange from Brazil was FIFA President from 1974 to 1998, while Teixeira was the former boss of the Brazilian Football Federation. He was also a FIFA executive committee member until

88 Noah Davis \& Juan Cappello, "Does FIFA’s Corruption Hurt the Beautiful Game” (2013) 7 Americas Quarterly 22; Samuel Morris, "Fifa World Cup 2022: Why the United States cannot successfully Challenge Fifa awarding the Cup to Qatar and how the Qatar Controversy shows Fifa needs Large-Scale Changes" (2012) 42 Cal West Intl L J 541; Guoying Yuan, Houzhong Jin, Hongquan Li and Si Liu, "Strategies to avoid Corruptions in FIFA" (2011) 6 Int'l J Bus \& Mgt 215; Kate Youd, "The Winter's Tale of Corruption: The 2022 FIFA World Cup in Qatar, the Impending Shift to Winter, and Potential Legal Actions against FIFA" (2014) 35 Nw J Intl \& Bus 168.

89 Youd, Ibid, see also "FIFA Corruption Crisis: Key Questions Answered" BBC News, 2 July 2015, online: $<$ http://www.bbc.com/news/world-europe-32897066>; Noah Davis, "The Series of Scandals have not only Tainted FIFA, but Undermined Trust in the Game as Well" Americas Quarterly, Summer 2013, online:

$<$ http://www.americasquarterly.org/content/series-scandals-have-not-only-tainted-fifa-undermined-trust-game-well $>$;

"The Guardian View on Corruption in FIFA: You Couldn't Make it Up" The Guardian (14 November 2014), online: $<$ http://www.theguardian.com/commentisfree/2014/nov/14/guardian-view-corruption-fifa-publish-garcia-report>.

90 ESPN Staff, "Blatter Raises Questions over 2006” ESPN FC, 15 July 2012, online: $<$ http://www.espnfc.com/story/1124830/fifa-president-sepp-blatter-raises-questions-over-2006-world-cup>.

91 Mark Ledsom, "Soccer-ISL Defendants Blame FIFA for Marketing Firm's Collapse" Reuters (3 April 2008), online: $<$ http://uk.reuters.com/article/2008/04/03/soccer-isl-trial-idUKL033261820080403>; see also Andrew Jennings, "FIFA 'misled' Detectives on Trail of Missing £45m paid for World Cup TV Rights” The Telegraph, 29 July 2008, online: $<$ http://www.telegraph.co.uk/sport/football/international/2470897/Fifa-misled-detectives-on-trail-of-missing-45m-paidfor-World-Cup-TV-rights.html>. 
resigning in 2012 for "personal reasons" as he claimed. But he had allegedly been under intense pressure to resign following allegations of corruption. ${ }^{92}$

Earlier in 2010, two FIFA executive members, Nigeria's Amos Adamu and Tahiti's Reynald Temarii were banned three years and one year respectively for demanding bribes in return for casting favourable votes in the choice for host cities of the World Cup tournament in $2018 .^{93}$ In Adamu's case, he met two Sunday Times of London undercover reporters who posed as businessmen from the United States and requested some $£ 500,000$ for "a personal project." In return, he was to vote for their preferred host candidate city for the 2018 World Cup bid. ${ }^{94}$ The meeting was secretly recorded without Adamu's knowledge. When asked if the money he requested for the personal project would have any effect on how he would vote in the bidding process, he responded, "[o]bviously, it will have an effect. Of course it will. Because certainly if you are to invest in that, [it] means you also want the vote." 95

Furthermore, a FIFA Vice President and head of the Asian Confederation, Qatar's Mohamed bin Hammam was forced to drop his candidacy for the office of President because of allegations of corruption. He was alleged to have distributed $\$ 5$ million in bribes to help his country win the hosting rights for the 2022 World Cup. ${ }^{96}$ Hamman would have contested against Blatter for the FIFA Presidency. He later resigned from his positions and was given a life ban from all FIFA activities. ${ }^{97}$ His life ban was later overturned by the Court of Arbitration for Sports.

It also emerged that Jack Warner had allegedly received payments of up to $\$ 1.2$ million from a company controlled by Bin Hammam prior to the votes for the 2022 World Cup bid process which Qatar eventually won. ${ }^{98}$ Warner's two sons were also said to have received an additional $\$ 1$ million in payments from the same company. These payments were ostensibly for work performed between 2005 and 2010 for Hammam's company by another company controlled by Warner named Jamad. The nature of the work that the company did was not stated. Warner was also accused of "seeking a bribe to help garner votes for Egypt's ill-fated bid to host the 2010 World Cup" 99 which South Africa ultimately won.

92 ESPN Staff, “Teixeira Quits FIFA Role” ESPN FC, 20 March 2012, online: ESPN FC $<$ http://www.espnfc.com/story/1037958/former-brazil-football-chief-ricardo-teixeira-quits-fifa>

93 Press Association, “Amos Adamu Banned by FIFA for Three Years after Corruption Hearing” The Guardian (18 November 2010) online: <http://www.theguardian.com/football/2010/nov/18/amos-adamu-banned-fifa-corruption>.

94 Sahara Reporters, "Nigeria’s Amos Adamu Offers to Sell FIFA Hosting Rights for £500,000” Sahara Reporters, 16 October 2010, online: <http://saharareporters.com/2010/10/16/nigerias-amos-adamu-offers-sell-fifa-hosting-rights$\%$ C $2 \%$ A $3500000>$.

95 See 'FIFA Launches Investigation into Vote-selling Claims" BBC Sport (17 October 2010), online: $<$ http://news.bbc.co.uk/sport2/hi/football/9099326.stm>.

96 See Agence France-Presse, "Mohamed bin Hammam accused of Payments to help Qatar World Cup Bid" The Guardian (1 June 2014) online: <http://www.theguardian.com/football/2014/jun/01/qatar-world-cup-bid-mohamed-bin-hammamaccused-further-payments>.

97 Reuters, "FIFA Bans Mohamed Bin Hammam for Life" The Globe and Mail (17 December 2012), online: $<$ http://www.theglobeandmail.com/sports/soccer/fifa-bans-mohamed-bin-hammam-for-life/article6474237/>.

98 See Owen Gibson, "Qataris paid FIFA Official \$1.2m after World Cup bid Win, Documents Claim” The Guardian (18 March 2014), online: <http://www.theguardian.com/football/2014/mar/18/qatar-fifa-jack-warner-world-cup>.

99 See "Ex-EFA Chairman: Warner sought Bribe from Egypt over 2010 World Cup Bid" Albawaba Sports (19 April 2015), online: <http://www.albawaba.com/sport/warner-egypt-2010-world-cup-684018>. 
These scandals occurred under Sepp Blatter as FIFA President but none of them seemed to have affected his position. As he deflected all questions regarding his integrity, the one concern that recurred was how he could affect such an image of rectitude in FIFA's seemingly vast empire of graft. He was, regardless, re-elected in 2015 to a fifth five-year term to the office he first assumed in 1998. In late 2015, he was banned from all football-related activities for signing a contract unfavourable to FIFA as well as making a "disloyal payment" to UEFA President, Michel Platini, effectively ending his tenure. Interestingly, when Havelange and Teixeira faced the prospect of criminal prosecution for the bribes they allegedly took as described earlier, FIFA under Blatter paid $£ 1.64$ million in compensation so that the criminal charges could be dropped. The question that arises is why would FIFA under Blatter pay such compensation if did not have anything to hide.

Further clues emerged when Swiss Magistrate Thomas Hildbrand investigated allegations that senior FIFA officials received bribes from ISL for over two decades (including obviously those given to Havelange and Teixeira) for which the company apparently earned exclusive marketing contracts to the World Cup. A police squad raided Blatter's FIFA headquarters, ${ }^{100}$ but former ISL executive Jean-Marie Weber refused in court to disclose the recipients of the bribe because "on the advice of my lawyer I have no statement to make... These payments were confidential and I must respect that confidentiality." "In the analytical section below, it will be shown how corruption from FIFA enables similar practices in its domestic affiliate football federations.

\section{LIKE A “DICTATORSHIP” LIKE FIFA}

That Sepp Blatter survived corruption storms that blew away other FIFA officials, while at first surprising, pointed to the next obvious deficit in FIFA's governance procedures. It is one most recently captured by Luis Figo, the iconic Portuguese who played the game at the very highest levels at Spain's Real Madrid and Barcelona. A former world player of the year, he also represented Portugal at the international level. Figo showed an interest to challenge Blatter for the FIFA presidency in 2015 but unceremoniously announced his withdrawal from the race through a statement in which he compared FIFA under Blatter to "a dictatorship."102 Many might think this to be an apt characterization given how fairly accurately it captures the manner that Blatter governed FIFA during his presidency. In addition, during a congressional hearing in 2013 prior to the 2014 World Cup that Brazil hosted, another legend of the game, Romario, branded Blatter a "thief" and the FIFA Secretary Jerome Valcke "a blackmailer." 103 Because of a heightened level of secrecy in its affairs, FIFA under Blatter was compared to the Cold War Soviet Union. ${ }^{104}$

\footnotetext{
100 Jennings, "Investigating”, supra note 4 at 396.

101 Andrew Jennings, "How FIFA Corruption Empowers Global Capital” in Collette Schulz Herzenberg ed., Player and Referee: Conflicting Interests and the 2010 FIFA World Cup (Pretoria: Institute of Security Studies, 2010$) 73$ at 88.

102 Ben Rumsby, "Luis Figo Quits FIFA Race with Scathing Attack on Sepp Blatter's 'Dictatorship" The Telegraph (21 May 2015), online: <http://www.telegraph.co.uk/sport/football/news/11621789/Luis-Figo-quits-Fifa-race-with-scathingattack-on-Sepp-Blatters-dictatorship.html>.

103 See "Former Brazilian Star Romario: 'FIFA is Corrupt"” Sports Illustrated (16 October 2013), online: $<$ http://www.si.com/soccer/2013/10/16/romario-criticizes-fifa-sepp-blatter-jerome-valcke>; see also Eduardo Fernandez-
} 
But more than these claims, some examples would seem to illustrate the self-evident dictatorial nature of FIFA's governance. Its corruption scandals were a source of irritation to a broad spectrum of the game's admirers around the world. These admirers recognized the organization's apparent unethical past but campaigned for a clean slate and a fresh start. This was easier said than done at least until recent events. In 2014, members of the European confederation who were Blatter's harshest critics forced a FIFA congress vote intended to prescribe age and term limits for FIFA officials, including the President. Blatter was not interested in those proposals though he allowed the vote to take place. He easily crushed his opposition as the delegates voted overwhelmingly against both ideas. Then, in victory, he dispensed some carrots: all 209 national affiliate associations were to receive $£ 450,000$ each while each of the regional confederations would get $£ 4.2$ million. ${ }^{105}$

Throughout his term, Blatter responded with both stick and carrot whenever he faced opposition from within or even outside FIFA. In terms of the stick approach, almost all those who had the courage to challenge Blatter within FIFA ended up in one or another form of ignominy. For instance, when Blatter initially won the FIFA presidency in 1998, Farah Addo, head of the Somali Football Federation and Vice President of the CAF, alleged that African delegates had been bribed just hours before the vote to switch camps in Blatter's favour. Issa Hayatou, the head of CAF, supported Blatter's sole challenger, Lennart Johansson, the Swede who was at the time President of the European confederation. Hayatou promised to deliver African votes to Johansson. Yet the latter lost the vote to Blatter by a margin of 80 to $111 .{ }^{106}$

So, what was it that made a lot of the African delegates change their minds so quickly in the last few hours before the vote? ${ }^{107}$ The story was that:

Only a short time before they had stood together hand in hand with Issa Hayatou, the chief of the African confederation CAF and FIFA vice president and promised their support for Johansson. The next day we talked to Hayatou. He confirmed that the talk was all about money, all night in the Meridien Hotel. Hayatou himself got a phone call around midnight as he was preparing to retire for the night. He was urged to come over immediately from his Hotel, the Bristol, to the Meridien. When he arrived there a lot of African delegates asked him how much money they could get from CAF. He also confirmed what other observers said: It was bargaining like in a bazaar. ${ }^{108}$

Abascal, "Brazil Legend Romario: FIFA President is 'Corrupt Thief"” International Business Times (13 March 2014), online: <http://www.ibtimes.co.uk/brazil-legend-romario-fifa-president-joseph-blatter-corrupt-thief-1440125>.

Richard Conway, "FIFA Crisis: Sepp Blatter 'Raging against the Dying of the Light"” BBC Sport (15 June 2015), online: $<$ http://www.bbc.com/sport/0/33141267>.

105 Charles Sale, "FIFA Delegates Grant Sepp Blatter a Job for Life with 78-year-old President Set for Fifth Term" Daily Mail (11 June 2014), online: <http://www.dailymail.co.uk/sport/football/article-2655618/FIFA-delegates-grant-SeppBlatter-job-life-78-year-old-president-set-fifth-term.html>.

106 Jens Weinreich \& Thomas Kistner, "Politics and Corruption in FIFA" Play the Game (14 November 2000), online: $<$ http://www.playthegame.org/news/news-articles/2000/politics-and-corruption-in-fifa/>.

107 Ibid.

108 Ibid. 
Though this claim of bribery for votes came to the knowledge of many within FIFA circles, Addo faced undue personal retribution for making it a public issue after the election. Blatter first won an injunction in a Swiss court barring Addo from repeating the allegation of bribery of African delegates. Subsequently, Addo was accused before the FIFA Disciplinary Committee (which Blatter appointed) of misusing money meant to help grass-roots football in Somalia. He was found guilty of embezzlement and banned 10 years from all football-related activities. Addo was also sentenced to $£ 40,000$ in fines and costs. ${ }^{109} \mathrm{He}$ died in 2008 before serving out the sentence.

In the 2002 election, Johansson returned Hayatou's 1998 favour by backing him against Blatter. The Cameroonian lost by an even wider margin - 56 to $139 .{ }^{110}$ Prior to this particular vote, Johansson and Hayatou sought to play the ISL collapse and the bribery scandal that erupted soon after against Blatter. They engineered an audit "to determine the true scale of FIFA's ISL-related losses." "111 Blatter suspended the audit committee report until after the election. Yet that did not stop then FIFA Secretary General Michael Zen-Ruffinen who himself detested Blatter's alleged dictatorial style from releasing a report that detailed corruption, financial mismanagement, and cronyism within FIFA's hierarchy. ${ }^{12}$ That too did not work. Instead, Zen-Ruffinen was forced to quit his post after Blatter was re-elected and so lost the power struggle between them. ${ }^{113}$

By the time of the 2007 election, Blatter had so cowed the field of potential challengers that no individual had the courage to run against him. He stood election as the sole candidate and was returned unopposed. ${ }^{114}$ In 2011 he ran unchallenged yet again, pushing aside the minimal resistance he faced. In the run-up to the anticipated vote, the head of the Asia Confederation Mohamed Bin Hammam announced his intention to challenge Blatter to the Presidency of FIFA in that year's congress. However, three days before the vote, Hamman withdrew his candidacy under a cloud of controversy. He was in fact prohibited from entering the venue where the vote took place. ${ }^{115}$

An ally of Blatter since 1998, Hammam was subsequently accused and charged before the FIFA Ethics Committee (appointed by Blatter) for allegedly bribing 25 members of the Caribbean Football Union with a total of \$1 million to secure their votes for Qatar's bid to host the World Cup in 2022. ${ }^{116}$ Blatter won the vote unopposed by a whopping $91.63 \%$ (186 votes out of a possible 203). An imaginative blogger compared this margin to that earned in different elections by those he called Blatter's "dictatorial counterparts" which include such ignoble characters as Iraq's Saddam Hussein,

\footnotetext{
109 See "FIFA Bans Addo for 10 Years" The Telegraph (22 July 2004), online:

$<$ http://www.telegraph.co.uk/sport/2383371/FIFA-ban-Addo-for-10-years.html $>$.

110 Paul Darby, "Africa, the FIFA Presidency, and the Governance of World Football: 1974, 1998 and 2002" (2003) 50 Africa Today 3 at 18.

111 Ibid at 16.

112 Ibid.

113 See “Zen-Ruffinen to Leave FIFA” BBC Sport (31 May 2002), online: <http://news.bbc.co.uk/sport2/hi/football/2017855.stm>.

114 See "Blatter Secures Third FIFA Term" BBC Sport (31 May 2007), online: < http://news.bbc.co.uk/sport2/hi/football/6518647.stm>.

115 See "Sepp Blatter Wins Re-election as President of FIFA" BBC Sport (1 June 2011), online: $<$ http://www.bbc.com/sport/0/football/13610973>.

116 See "Rise and Fall of Mohamed Bin Hammam-Timeline" The Guardian (1 June 2014), online: $<$ http:/www.theguardian.com/football/2014/jun/01/mohamed-bin-hammam-timeline $>$.
} 
Islam Karimov of Uzbekistan, Zaire's Mobutu Sese Seko, Syria’s Bashar al Assad and Rwanda's Paul Kagame. ${ }^{117}$

Ahead of the 2011 election, Blatter vowed that, if he was re-elected, he would stand down from the post in 2015. Addressing a meeting of the European Confederation in March of that year, he said: "You know I aspire to another four years... [But] these will be the last years for which I stand as candidate." 118 As it turned out, Blatter could not resist the temptation of the office for long. He recanted this promise and contested again in 2015. So, while it could not be stated that the length of his tenure is the only evidence of dictatorship, the manner in which he was re-elected over time and especially how he treated those opposed to him suggested a strong inclination towards dictatorship on his part.

\section{FIFA ENTHRONES POWER AND IMPUNITY}

Dictatorship often moves hand in hand with impunity. And while the single events described in the previous section might portray Blatter as the sole culprit in FIFA's characterization as a dictatorship, it speaks to a larger culture in its entire set up and modus operandi. The system appears not to have been programmed for democratic accountability, particularly with regard to the presidency of the organization. For example, following the most recent avalanche of corruption scandals that it had to deal with, FIFA invited the corruption watchdog group Transparency International [TI] to work with it in cleaning up its business. The relationship collapsed as quickly as it was established over methods.

When FIFA hired an independent expert to supervise major reforms in the organization, TI recommended that the expert should not be paid by FIFA so as not to compromise his independence. The private expert also said, in carrying out his assignment, he would not reopen or re-examine old scandals. ${ }^{119}$ TI had recommended that those records must be brought to the open especially the report on the bidding process for the 2018 and 2022 World Cup tournaments. ${ }^{120}$ TI had also been in the forefront of campaigns for term limits at FIFA. This call, as earlier stated, has not been honoured such that, if Blatter had served out the four-year term he won after the 2015 election, he would have been FIFA head for 21 years. Havelange, whom Blatter replaced, was President for 24 years, while Stanley Rous had served 13 years by the time he lost to Havelange in 1974.

It could be argued that dictatorships are not formed simply by reference to number of years spent in office. Yet that would be looking at it literally. To fully understand FIFA's dictatorial governance structure would require combining extended tenures with other characteristics of dictatorial regimes and institutions. For example, while the fact that FIFA elections are held at regular intervals gives the appearance of democratic culture, but it still has to be considered how fair are the nomination procedures and whether the playing field is level at all times for would-be contestants.

117 See "Sepp Blatter's FIFA Re-Election in the Proper Perspective" (1 June 2011), Free Beer Movement Blog, online: $<$ http://freebeermovement.blogspot.ca/2011/06/sepp-blatters-fifa-re-election-in.html $>$.

118 See "FIFA President Sepp Blatter 'to stand down in 2015"” BBC Sport (22 March 2011), online: $<$ http://news.bbc.co.uk/sport2/hi/football/9432196.stm>.

119 See "Transparency International Cuts Ties with FIFA" BBC News (2 December 2011), online: $<$ http://www.bbc.com/news/world-europe-15996806>.

120 See "FIFA: Time to Change" (12 June 2014) Transparency International, online: $<$ http://www.transparency.org/news/feature/fifa_time_to_change $>$. 
The life term culture prevalent in FIFA has understandably been copied by the confederations, especially those in the Third World. In 2015, Hayatou the African confederation President would have been in charge for 27 years. Until being forced out, Jack Warner held the Presidency of the CONCACAF region for 21 years. Even more bizarre, before dying in office in 2014, Julio Grondona had been head of the Argentinian FA for 35 years, 26 of which he also served as FIFA Vice President. At the time of his death, he was aged $82 .{ }^{121}$ This raises the question, if sit-tight dictatorships are considered no longer fashionable in the real world, why it is such an attraction for FIFA.

The answer could be in how FIFA has managed to insulate itself from best practice rules of democratic accountability. In a 2011 report, TI had likened FIFA to a multinational corporation but one with a warped governance structure. According to the organization:

[U]nlike a multinational company, answerable to shareholders, FIFA's mandate comes from the member federations represented by officials (i.e. presidents and delegates, mostly working on a voluntary basis) from all over the world, elected bottom up. This means that FIFA is answerable to the 208 national football associations who themselves are partly dependent on the funds that FIFA allocates to them. This lack of mandatory accountability to the outside world makes it unlikely that change will come either from within the organisation or from the grassroots of the football organisations. Moreover, the scale and specific structure of FIFA makes it difficult to adapt what is considered best business practice to the governance challenges it is facing. ${ }^{122}$

Before looking at the "grassroots" structure, which TI says cannot drive FIFA towards accountability, it bears noting that FIFA's own accountability deficits tend to draw it towards regimes and institutions with which it shares those deficits in common. This is obviously the reason it rarely uses the authority of its hosting rights to affect any kind of social or political ethics around the world. In fact, FIFA's mindset is captured by a 2013 statement attributed to former Secretary General, Jerome Valcke. Though recognizing that it sounded "crazy", he still asserted that "less democracy is sometimes better for organizing a World Cup." 123 This might explain the manner FIFA rewards undemocratic regimes with its competitions; from the military in Nigeria (1999 sub-20 competition) to Qatar's Islamic monarchy (2022) World Cup and to Russia (2018 World Cup) with its expansionist belligerence and widely acknowledged racism problems. ${ }^{124}$

\footnotetext{
121 “Julio Grondona: FIFA's Senior Vice President dies at the Age of 82” BBC Sport (30 July 2014), online: $<\mathrm{http}: / /$ www.bbc.com/sport/0/football/28575350>.

122 Sylvia Schenk, Safe Hands: Building Integrity and Transparency at FIFA (Berlin: Transparency International, 2011) at 2, online: Transparency International $<\mathrm{http}: / /$ issuu.com/transparencyinternational/docs/fifa safehands? $=2496456 / 2710188>$.

123 See "Soccer: Less Democracy Makes for an easier World Cup - Valcke" Reuters (24 April 2013), online: $<$ http://www.reuters.com/article/2013/04/24/us-soccer-fifa-idUSBRE93N18F20130424>.

124 "Russian FA Chief: Football must deal with 'Virus' of Racism” BBC Sport (3 March 2015), online: $<$ http://www.bbc.com/sport/0/football/31717314>; see also “FIFA's Sepp Blatter 'Concerned' by Russia Racism Report” BBC Sport (2 March 2015), online: <http://www.bbc.com/sport/0/football/31688474>.
} 
Now turning to the "grassroots" that TI mentioned, it is clear that the domestic federations, especially those in the Third World, nourish themselves from the carrots FIFA throws them from time to time. This renders them incapable of enforcing any kind of accountability in FIFA's governance. To merit affiliation to FIFA in the first place, they must subscribe to Article 13(1) (i) of the 2014 edition of its Statutes, which provides that members owe an obligation "to manage their affairs independently and ensure that their own affairs are not influenced by any third parties." ${ }^{25}$ It has previously been discussed how receiving public funding by these FAs, especially those in the Third World countries, does not count as undue influence or interference in FIFA's books. Yet, when governments which provide the funds demand accountability for those funds, FIFA promptly waves the interference flag.

Given its wealth, FIFA also has access to a pot of cash that it distributes from time to time to affiliate federations. As it resists efforts to hold it down to some level of financial ethics, it hardly requires its affiliate federations to account for the monies they receive from it except when they challenge Blatter, as Addo of Somalia learned to his detriment. And because Blatter was the most generous in doling out these funds throughout his first tenure, chances of even more largesse apparently persuaded these FAs (especially those in Africa) that they could not possibly have a better deal outside Blatter. That is probably why they voted for him against Johansson in 1998. It is this reason too they voted against their own leader Hayatou when he challenged Blatter in 2002. They voted for Blatter again in 2015 because, as Kalusha Bwalya who heads the Zambian FA claimed "[i]n this situation we have made a commitment to President Sepp Blatter. We are happy with the way he has run things." ${ }^{126}$

It might look as if African and other Third World football federations held Blatter too close to their hearts for no reasons at all. That is clearly not the case. That they did is also not all negativity. Blatter helped the growth of the game, not just in the Third World but across the globe. During his time as President he followed up on the democratization of the organization started under his predecessor, Havelange. He did so in a manner that had never been done before, both in terms of distributing FIFA's enormous financial resources and also by pluralizing certain aspects of its decision-making procedures. All affiliate federations had a single vote irrespective of their country size and economic status. Some journalists in Europe and the United States considered this to be the root of the institution's corrupt practices. ${ }^{127}$ This suggestion is, however, dismissed as proof of the most powerful nations in FIFA setting up a straw-man argument in order to seize control of the organization and abolish its appearance of inclusivity. ${ }^{128}$

It was more than the money that FIFA under Blatter routinely distributed to its affiliate federations; there was the more destructive practice of the immunity FIFA under Blatter conferred upon them against their home governments to not account for any monies received; not those granted by their governments and certainly not those distributed by FIFA. This makes FIFA a very dangerous transnational organization on many levels. As a former England National Team Manager, Graham Taylor, observed:

\footnotetext{
125 See "FIFA Statutes: August 2014 Edition" online:

$<$ http://www.fifa.com/mm/document/affederation/generic/02/41/81/55/fifastatuten2014_e_neutral.pdf $>$.

126 Kennedy Gondwe, "Bwalya believes it is too Early for Figo to Challenge Blatter" BBC Sport (7 March 2015), online: $<\mathrm{http}: / /$ www.bbc.com/sport/0/football/31780164>.

127 Elliot Ross, “The End of Sepp Blatter must not mean the End of Inclusiveness in Football” The Guardian, (4 June 2015), online: <http://www.theguardian.com/football/commentisfree/2015/jun/04/sepp-blatter-football-fifa-corruption>.

128 Ibid.
} 
"You have got in FIFA an organization that doesn't have to answer to anyone, even governments. If governments get involved, FIFA suspends the national team."129 When a Nigerian Assistant Coach, Sylvanus Okpala, was sacked by the Nigerian FA, (according to him unfairly), he appealed to the President of the association for recourse. The answer he got staggered him. Okpala narrated:

He also said that if I like I should as well go and report him to the president of Nigeria, [...] stressing, "even if the president calls me to pay you, I will not pay, after all I am not under the Federal Republic of Nigeria but under FIFA. If anything happens to me, FIFA will ban Nigeria. ${ }^{130}$

The active word here is "ban" and the questions are: why is the relationship that FIFA has with national federations so important? Why is it so difficult for governments to ignore FIFA and insist on setting the rules by which their FAs should operate? The answer is that the governments cannot assert their sovereignty because they are vulnerable to the impunity that FIFA has accumulated on account of the love that ordinary people have for the sport.

The game is very popular in many countries to the point of religious worship. The worshippers do not care about FIFA, their FAs or governments. They want only to see the games live or on television. ${ }^{131}$ They also want to see their national teams represented even for all the corruption in the world. FIFA knows this too well. Often when FIFA threatens to suspend erring FAs because of "government interference", no further action is required on its part to make the governments buckle under its pressure. The indignation is mostly generated from below - through advertisers who will lose revenue if national teams are ejected from competitions, citizen lovers of the game who just want to see it live or on television, politicians who would not want to be remembered as those who caused their teams to be ejected, media personnel (especially from the Third World) who will have limited incentive to cover international tournaments and therefore are denied the financial benefits they could get.

\section{CAN FIFA PASS THE TWAIL TEST?}

There is a lot that the concerns of TWAIL scholarship tell us about FIFA's transnational governance characteristics. Some of those insights engage the several ways that FIFA's activities impact the Third World, as well as how those activities mirror the inequality that dominates it as it does other institutions of governance in international law. FIFA has been shown to be afflicted by the three vices of corruption, dictatorship and impunity. These are challenges, the brushstrokes of which may not be used to tar all Third World countries. But they present significant problems in the majority of them. It is not far-

129 See "England 2018 Boss Andy Anson calls for FIFA Reform” BBC Sport (3 December 2010), online: $<$ http://news.bbc.co.uk/sport2/hi/football/9253733.stm>.

130 Patrick Omorodion, "NFF had Hand in my Mother's Death - Okpala" Vanguard (29 March 2014), online: $<$ http://www.vanguardngr.com/2014/03/nff-hand-mothers-death-okpala/> [emphasis added]

131 See Piekle Jr., supra note 8 at 9: "Most people care about what happens on the pitch, and not in the smoky back rooms of football governance". 
fetched that, given FIFA's awesome regulatory powers, the more questionable governance practices it allows could trickle down to Third World environments.

Before looking at the specific possible implications of these vices, it might be helpful to mention the ways that previous TWAIL writings had provided a critique of international institutions and how their praxis provides a window to FIFA's own reality. It is from this that I have developed what I call the TWAIL test of inclusivity, non-discrimination, minimal intrusion into sovereign authority, and accountable governance for the evaluation of international organizations. Before now, a Third World reading of most international institutions shows that they are generally undemocratic (despite appearances to the contrary) and unrepresentative. They all too often do not reflect the needs and interests of the developing world. ${ }^{132}$ Since 1904 FIFA has had eight Presidents. All but one of them was European. Up to and including the 1978 World Cup tournament in Argentina, Africa had just one representative in a 16-team format. This has been increased to five in a 32-team format.

It should come as no surprise though that Africa barely secured a guaranteed seat for the World Cup tournament. This was only after the continent boycotted the 1966 tournament that England hosted. As well, only during the terms of Havelange and Blatter as President did FIFA operate in some democratic decision-making fashion. According to one writer, "[i]nternational soccer hasn't always been inclusive, and there is no guarantee it will remain so if the rich countries who've been loudest about Blatter's sins regain control." 133 As much as FIFA under Blatter has concerned Africa for all the reasons already highlighted, it has to be admitted that what happens to FIFA after Blatter should also be of interest. There is fear that, under any form of European capture, FIFA might again transform to the less inclusive body it once was. ${ }^{134}$

Part of the idea of TWAIL, Gathii claims, is to bring the colonial encounter between Europeans and non-Europeans to the centre of historical re-examination of international law. ${ }^{135}$ If global governance institutions like FIFA are added to the mix, it means that TWAIL can offer a similar explanation to the colonial warrant of FIFA's history and how this came to shape the relationship among imperial powers and the postcolonial states within FIFA as well as its governance performance. There is a "dynamic of

132 See Klaus Dingwerth, "Private Transnational Governance and the Developing World: A Comparative Perspective" (2008) 52 Intl Stud Q 607.

133 Elliot Ross, "The Sepp Blatter Era in World Soccer is already ending. Fans may Wind up Missing Him" The Washington Post (1 July 2015), online: <https://www.washingtonpost.com/posteverything/wp/2015/07/01/the-sepp-blatter-era-inworld-soccer-is-already-ending-fans-may-wind-up-missing-him/>; continuing, he states: "After all, the future of soccer is now up for debate in a way not seen since 1974, when the iron grip of Europe over FIFA was broken. Up until then, FIFA had been run as a club for big powers like England, France and Germany. The FIFA president between 1961 and 1974 was a patrician Englishman, Stanley Rous, a supporter of apartheid who fought to protect South Africa's membership in FIFA when every other African and Asian nation wanted it expelled. Africa only got a guaranteed spot at the men's World Cup in 1970, after boycotting in 1966. The coalition that eventually defeated Rous was marshaled by the Brazilian João Havelange, and subsequently by Sepp Blatter."

134 See "FIFA: Michel Platini wants FIFA Job but Prince Ali is Unhappy" BBC Sport (29 July 2015), online: $<$ http://www.bbc.com/sport/0/football/33700638>.

135 Gathii, "History", supra note 16 at 30. See also James Thuo Gathii, "International Law and Eurocentricity" (1998) 9 Eur J Intl L 184. 
difference" 136 as Gathii describes it within FIFA's operating procedure which feeds the unequal treatment of its affiliates on the basis of their status as developed or Third World states.

For the above reason, the discriminatory regulations that FIFA prescribes for countries hosting its tournaments provide the first example of how inequality plays out in practice. FIFA tends to treat Third World host states differently than it does host states that are developed. The examples of South Africa and Brazil (compared to Germany) as hosts of the World Cup demonstrates the claim. Third World countries tend to have more stringent hosting requirements prescribed for them. FIFA also intrudes far more deeply into their sovereign status and is more skeptical of their infrastructure and rule of law standards. There is the hint as well as actual demonstration of inequality, unfairness, domination, subordination and disadvantage in this relationship. They are not only concerns of TWAIL, ${ }^{137}$ but to the extent that FIFA's demand in this area established new social norms or affected legal/non-legal rules and standards at the national level, it meets Dingwerth's criteria for the normative/regulatory effect of the process of private regulation. ${ }^{138}$

FIFA is often ranged alongside domestic football administrators to frustrate or upset national legal orders. Its variant of private governance (once it is agreed that FIFA is actually private) therefore backs institutions of public power up against the wall, bending them to its will. This is of concern from a Third World perspective. It produces adverse consequences like those for which global International Finance Institutions [IFIs] have become especially notorious over the years. ${ }^{139}$ It makes sense therefore that the same questions that are asked of IFIs in the transnational governance context are also put to FIFA. What, for example, are the limits of FIFA's powers in its dealings with the Third World? In what ways can it be held legally accountable for the decisions it makes that affect these countries? ${ }^{140}$

FIFA's corruption problem in particular has far reaching consequences as it could be fostering the social problem in countries of the Third World and thereby making an already bad situation worse. It is not in doubt that corruption though a worldwide challenge is more problematic in Third World countries. Their governments would therefore need all the help they can get to combat it. But FIFA's governance practices relative to its domestic affiliate federations in the Third World tends to move in the opposite direction by protecting the game's domestic administrators from legal/governmental scrutiny. As stated earlier, FIFA sees any effort to get local football federation officials to account both for funds they received from the government as well as those from FIFA as interference from a third party. ${ }^{141}$

Not only does FIFA shield domestic football administrators from legal accountability, it is becoming increasingly obvious that hosting rights could be won by bribing FIFA officials. In addition, the mere fact that the hosting right is granted often is no guarantee that the tournament will be held in the chosen

136 Gathii, "History", supra note 16 at 31.

137 See Okafor, supra note 15 at 176.

138 Dingwerth, supra note 132 at 610.

139 Antony Anghie, "Time Present and Time Past: Globalization, International Financial Institutions, and the Third World" (2000) 32 NYU J Intl L \& Pol 243 at 244.

$140 \quad$ Ibid at 264.

141 See "FIFA Bans Kenya" BBC Sport (2 June 2004), online: <http://news.bbc.co.uk/sport2/hi/football/africa/3769627.stm>; see also "Kenya Accuses KFF and FIFA" BBC Sport (2 June 2004), online: $<$ http://news.bbc.co.uk/sport2/hi/football/africa/3771211.stm>; "FIFA Suspends Cameroon but Awards them Win over Togo" BBC Sport (4 July 2013), online: <http://www.bbc.com/sport/0/football/23182334>. 
country. It appears the hosting right has to be oiled and maintained until the tournament is actually held. In the graft-infested world of FIFA, this could open a channel through which its officials are able to blackmail governments often desperate to build political capital out of hosting FIFA tournaments.

Nigeria again provides a near perfect example of this trend. The country hosted the FIFA sub-20 tournament in 1999 under a military dictatorship and the sub-17 tournament in 2009 long after civil rule had been restored. On both occasions, Jack Warner who resigned as FIFA's Vice President because of allegations of corruption and is among those now facing indictment for taking bribes to sell the World Cup 2022 hosting rights to Qatar, headed the FIFA facilities inspection team. On those occasions, Nigeria never seemed to be ready according to Warner until very close to the commencement of the events.

For the 1999 tournament, after scathing negative comments he made about Nigeria's state of preparedness as host, Warner returned barely weeks later to intimate that the country had pulled off the eighth wonder of the world! ${ }^{142}$ This raises the question what, in a context of vibrant corruption, could have transpired between those two visits to cause such a swift change of circumstances. There might be temptation to dismiss that occurrence as a storm in a tea cup; but it seems to fit into a pattern in FIFA's dealings though it may not always get away with such blackmail. Prior to the 2014 World Cup tournament in Brazil, then FIFA Secretary General Jerome Valcke had stated that the country was more concerned about winning the tournament than getting the facilities ready, and needed a "kick up the backside" to reset its priorities. Brazil rejected the statement, describing it as "unacceptable."143 FIFA and Blatter were forced into an apology. ${ }^{144}$

In the final analysis, it is fairly predictable that FIFA may not pass the TWAIL test for the reasons discussed above. Granted, while under Blatter the organization tried to balance off the muscle and history of its Eurocentric roots with formal democratic representation, this only masked deeper issues in its relationship with the Third World. This is not only in terms of its massively Europeanized structures but also the disproportionate impact of its decision-making and governance practices on the developing countries of the global South.

142 Olufemi Akinsola, et al, "Evaluation of Scenarios of Facilities Maintenance Management of Sports Complexes in South West Nigeria" (2012) 5 J Sustainable Dev 99 at 100; see also "FIFA Inspectors shocked by decaying Facilities in Lagos" Xinhua News Agency, 21 February 2008, online: <http://www.china.org.cn/eng-lish/sports/243464.htm>; Warner was mentioned again in relation to a $\$ 10$ million payment made by South Africa regarding its hosting of the 2010 World Cup. The country claimed it was not a bribe. See James Whaling, "South Africa FA admit they paid \$10 million to host 2010 FIFA World Cup - But deny it is a Bribe" The Mirror (31 May 2015), online: <http://www.mirror.co.uk/sport/football/news/south-africa-fa-admit-paid-5799765>; see also Ben Rumsby, "FIFA in Crisis: South Africa 'paid out $£ 6.5$ million in Bribes’ to Jack Warner and Chuck Blazer to win 2010 World Cup" The Telegraph (28 May 2015), online: <http://www.telegraph.co.uk/sport/football/fifa/11634908/Fifa-in-crisis-South-Africapaid-out-6.5m-in-bribes-to-Jack-Warner-and-Chuck-Blazer-to-win-2010-World-Cup.html> 


\section{CONCLUSION}

In this article, the international governance characteristics of FIFA have been utilized to exemplify how under-researched transnational regulatory institutions foster same exclusionary qualities as more traditional frames and actors in the field of traditional international law. It provides some evidence of the nature of FIFA's governance characteristics in question and argues that they have more intense impact on the Third World than the more developed societies of the global North even if there is an appearance of democratic decision-making.

The whole idea is to draw attention to institutions like FIFA that seem to have eluded the radar of academic scrutiny and point out that they deserve as much attention as other institutions and actors on the global arena that have been the subjects of such inquiries. This paper approached the issue of FIFA's place in the architecture of transnational governance from a TWAIL perspective. It examined the utility and suitability of the TWAIL framework for the evaluation of an institution like FIFA, which regulates a sports body that some could argue is removed from the world of international politics, governance and law. The article also argued that FIFA is as much a significant global governance actor as any that have been recognized as such in academic literature.

In the Third World context, FIFA has also been portrayed as warranting more than cursory attention. The rules that FIFA makes, as well as its other regulatory actions, have the tendency and potential to exacerbate recurring social and legal challenges in many Third World states. The reasons why this outcome is feared are not far to seek. The most important of the reasons perhaps is that most of these Third World states are structurally and institutionally weak and therefore more likely to imbibe wrong values such as corruption and abuse of power. FIFA has been shown to practise these wrong values and therefore its regulatory powers could be a source of socio-legal contamination if not closely monitored like similar global actors.

This requires putting pressure on FIFA to change its governance mechanisms such that they become more accountable and representative. Governments of Third World states should also start paying closer attention to FIFA and by extension its domestic affiliates in their respective countries. The current situation where FIFA seems to be sharing sovereignty with governments and coming up top most of the time is unhealthy. Besides, other government institutions like the courts must exercise sensitivity in mediating conflicts arising from doubts over the true nature of FIFA's powers. 